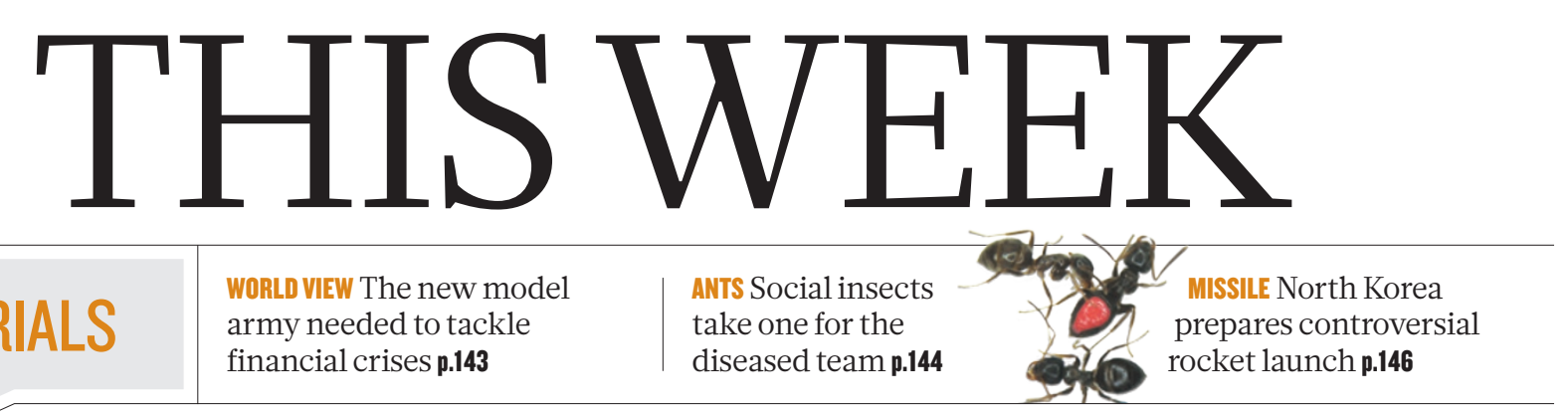

\title{
Buyer beware
}

\section{An investigation by Nature shows the scale of the market for unapproved stem-cell therapies in China. Hype and unrealistic hope must not be allowed to undermine genuine promise.}

$\mathrm{O}$ $\mathrm{n}$ the Internet, you can find advertisements for stem-cell remedies for every kind of disease or injury. Companies also promise that the cells will improve appearance or provide a 'rejuvenating' energy boost. The message - that stem-cell therapies need some work, but are an accepted part of medicine - is as clear as it is wrong.

But repeat this mantra enough - as it is repeated endlessly online - and the promises can start to seem real. In some places, they certainly look real. As we reveal on page 149, these 'cures' are offered in real clinics in China, where real nurses and doctors inject people with stem cells in various formulations from various sources - apparently convinced that they are helping patients. It looks and feels routine.

China has tried to crack down on unapproved treatments and it is not the only place where patients can buy these therapies: stem-cell companies also take advantage of gaps in regulation enforcement in the United States (see Nature 483, 13-14; 2012). But in China the problem is more widespread.

Promoters of such unproven and unapproved 'treatments' liken stem-cell therapy to other once-revolutionary therapies, such as organ transplantation. Doctors confess that they can't guarantee that the stem cells will work, but they do guarantee that the procedures are safe. If they weren't, say advocates, we would hear about it. So why not try?

This circular logic makes the apparent infiltration of stem-cell technologies into the medical mainstream even more worrisome. The more willing patients and medics are to believe, the less they look for true clinical data, and the less doctors are forced to produce it.

Compare the emergence of stem-cell therapies with the introduction of psychosurgery. Like stem-cell practitioners today, doctors in the 1930s and 1940s felt that the need for lobotomy was urgent enough to bypass the requirement for clinical evidence. Results were reviewed selectively, with pacifying brain damage sometimes taken as a stabilizing 'cure' for schizophrenia or nervous disorders. One promoter even shared the 1949 Nobel Prize in Physiology or Medicine for his part in developing the procedure. There was no long-term follow-up. In the end, doctors mutilated the brains of thousands of patients over the course of decades before critics were able to cast enough doubt on lobotomy to

\section{"Acceptance halt its use. The widespread acceptance made} is already overtaking

clinical evidence, with no systematic follow-up." it difficult for people to realize that these procedures were actually doing harm: you don't see a problem if you don't bother looking for it.

Of course, there is much legitimate research into stem cells, including many controlled clinical trials. It would be a shame if they were tainted by association with historical failures. However, judging from Nature's investigation in China, acceptance is already overtaking clinical evidence, with no attempt at systematic follow-up of treatments. If stem-cell therapies result in cancer or immunological disease, no one will know.

This does not stop people from outside China flocking to the country to take advantage of the stem-cell therapies offered there and promoted online with glowing endorsements. The clinics are certainly set up to make foreigners feel at home. Set aside from the teeming Chinese hospitals, stem-cell treatment centres have orderly nurse stations, welllit rooms and good bedside care. What is lacking is controlled clinical trials, reliable data and government approval. If the dedicated medical workers at the clinics don't see the problems, they need to look harder. If they really want to help their patients, they should seek to prove that the treatments work, rather than just assuming that they do. .

\section{Honest work}

\section{The plagiarism police deserve thanks for defending the honour of the PhD.}

L ast week, Hungary's President Pál Schmitt was forced to resign because of plagiarism detected in his $1992 \mathrm{PhD}$ thesis on physi$\checkmark$ cal education. Tivadar Tulassay, rector of Budapest's prestigious Semmelweis University, showed admirable courage by standing up to the Hungarian establishment to revoke the thesis a few days earlier, after experts appointed by the university declared that Schmitt's thesis "failed to meet scientific and ethical standards". Tulassay, a cardiovascular researcher, has since assumed personal responsibility for his university's decision to revoke Schmitt's title.
The affair has remarkable parallels with that of Germany's former defence minister, Karl-Theodor zu Guttenberg, who resigned in March last year after his own $\mathrm{PhD}$ thesis, in law, had been revoked by the University of Bayreuth.

Like Schmitt, zu Guttenberg tried at first to deny plagiarism charges, then to underplay them, and he enjoyed powerful political support until protests by a movement of honest $\mathrm{PhD}$ holders made his situation untenable. Plagiarism hunters have other prominent personalities in their sights, and are not necessarily going to be stopped just because a thesis is not in electronic form - if suspicion is high, they will digitize it themselves.

In many central European countries, an academic title is a decided advantage for a political career; clearly, some ambitious politicians think nothing of obtaining such a title by cheating. We can thank the plagiarism hunters - whatever their individual motives - for exposing dishonesty among those who govern us, and for defending the honour of a PhD. The only safe doctorate these days is an honestly acquired one. 